Amaltea. Revista de mitocrítica

ISSN-e: 1989-1709

http://dx.doi.org/10.5209/AMAL.57200

\title{
Editorial: Mito y cine en el siglo 21
}

José Manuel Losada

La representación del mito en las artes estáticas presenta aspectos de una contradictio in terminis: ninguna de ellas (escultura, pintura, dibujo, grabado, fotografía, arquitectura, instalación artística, body art...) refleja directamente el dinamismo de un relato mítico. En cambio, con excepción de la música, las artes del movimiento (teatro, danza, ópera, performances,...) combinan espacio y tiempo, permiten que el fenómeno mítico ocurra y discurra.

Estructurado en forma de relato, el cine parece el arte idóneo para la representación del relato mítico: contiene las ventajas de las artes plásticas, escénicas y musicales. Muchas películas contemporáneas adaptan mitos antiguos (Troy, Wolfgang Petersen, 2004), medievales (Excalibur, John Boorman, 1981) o modernos (Nosferatu, F.W. Murnau, 1922, Frankenstein, James Whale, 1931, Don Juan en los infiernos, G. Suárez, 1991, Faust, Alexander Sokurov, 2011). Otras han optado, desde los primeros vagidos del $7^{\circ}$ arte, por la ciencia ficción (Voyage dans la lune, Georges Méliès, 1902), dejando así el camino expedito para largas discusiones sobre la relación entre este género y la mitología (Metropolis, Fritz Lang, 1927; Her, Spike Jonze, 2013).

La aceptación del público ha sido desigual según los casos, y la profusión de mitos en la gran pantalla ha debido convivir con su representación en el resto de las artes, prueba de que el cine no agota las posibilidades del mito. Se impone un estudio profundo, teórico y práctico, sobre el lugar que la mitología ocupa en el cine, sobre las aportaciones de la técnica cinematográfica al relato mítico y sobre el cambio en la percepción del mito en la mujer y el hombre de hoy como consecuencia de su relación con el cine.

Los artículos de este noveno volumen de Amaltea, cuidadosamente seleccionados entre los muchos recibidos, se adaptan perfectamente a esta problemática entre mito y cine en nuestros días. El número incluye, además, una entrevista al cineasta bra-sileño Júlio Bressane (https://en.wikipedia.org/wiki/J\% C3\%BAlio_Bressane), que tiene en su haber más de 30 películas, y aporta aquí interesantes re lexiones sobre cine y mitología. Como de costumbre, el número incorpora un elenco de reseñas sobre mitocrítica.

¡Buena lectura! 


\section{[en] Myth and Cinema in the 21st Century}

The representation of myth in the static arts constitutes, in part, a contradictio in terminis. None of them (sculpture, painting, drawing, engraving, photography, architecture, body art, installation art...) reflects the dynamism of a mythic tale. However, with the possible exception of music, moving arts (theatre, dancing, opera, performances...) combine space and time and thus allow for the mythical phenomenon to occur and flow.

With its narrative structure, cinema seems to be the ideal form of art to represent myth: it includes the advantages of visual, scenic and musical arts. Many contemporary movies adapt ancient (Troy, Wolfgang Petersen, 2004), medieval myths (Excalibur, John Boorman, 1981) or modern myths (Nosferatu, F.W. Murnau, 1922, Frankenstein, James Whale, 1931, Don Juan en los infiernos, G. Suárez, 1991, Faust, Alexander Sokurov, 2011). Other films, since the early stages of the medium, have chosen science fiction as a genre (Voyage dans la lune, Georges Méliès, 1902), paving the way for works in which sci-fi and myth seem to compete (Metropolis, Fritz Lang, 1927, Her, Spike Jonze, 2013).

Audience response has varied the cases, and the profusion of myths in the big screen has learned to coexist with mythical representations in other arts, proving that cinema does not extinguish the possibilities of myth. Thus, it becomes necessary to conduct an in-depth study, both theoretical and practical, of the spaces that mythology occupies in films, the contributions of cinematic technologies to mythical tales, and how men and women's perceptions of myth have changed today through the relationship between myths and movies.

The articles of this volume, thoroughly selected among those received, fit conveniently to this problematic issue. The volume also contains an interview with Júlio Bressane (https://en.wikipedia.org/wiki/J\%C3\%BAlio_Bressane), Brazilian director of more than thirty films, who offers us very interesting reflections on our subject. As usual, several reviews on books about mythcriticism are offered to our readers.

Good reading!

José Manuel Losada www.josemanuellosada.com/en 


\section{[fr] Mythe et cinéma au 21e siècle}

La représentation du mythe dans les arts statiques peut paraître une contraditio in terminis : aucun de ces arts (sculpture, peinture, dessin, gravure, photographie, architecture, installation art, body art...) ne reflète directement le dynamisme du récit mythique. En revanche, et à l'exception de la musique, les arts du mouvement (théâtre, danse, opéra, performances...) allient espace et temps : ils participent du phénomène mythique et contribuent à son développement.

Structuré sous forme de récit, le cinéma semble être l'art idoine pour la représentation du récit mythique : il contient les avantages des arts plastiques, scéniques et musicaux. Nombre de films contemporains adaptent des mythes anciens (Troy, Wolfgang Petersen, 2004), médiévaux (Excalibur, John Boorman, 1981) ou modernes (Nosferatu, F.W. Murnau, 1922, Frankenstein, James Whale, 1931, Don Juan en los infiernos, G. Suárez, 1991, Faust, Alexander Sokurov, 2011). D'autres réalisations s'orientent plutôt, dès les prémices du cinéma, vers la science-fiction (Voyage dans la lune, Georges Méliès, 1902), ouvrant ainsi la voie à une apparente concurrence entre ce genre et la mythologie (Metropolis, Fritz Lang, 1927 ; Her, Spike Jonze, 2013).

L'accueil du public a été variable selon les cas, et la multitude de mythes sur grand écran a dû cohabiter avec celle présente également dans les autres arts, signe que le cinéma n'épuise pas les possibilités du mythe. Une étude approfondie, théorique et pratique, sur la place occupée par la mythologie au cinéma, sur les apports de la technique cinématographique au récit mythique et sur le changement provoqué par le cinéma dans notre perception du mythe s'impose donc aujourd'hui.

Les articles de ce volume, soigneusement choisis parmi tous ceux que nous avons reçus, répondent parfaitement à la problématique du mythe et du cinéma aujourd'hui. Ce volume comprend, en outre, un entretien avec Júlio Bressane (https:// en.wikipedia.org/wiki/J\%C3\%BAlio_Bressane), qui a dirigé plus de trente films. Il nous offre d'intéressantes réflexions sur les rapports entre cinéma et mythologie. Comme d'habitude, le volume contient plusieurs comptes rendus sur les mythes.

Bonne lecture !

José Manuel Losada www.josemanuellosada.com/fr 